\title{
America's Polarized Politics: Causes and Solutions
}

\author{
Morris P. Fiorina
}

\begin{abstract}
Our Divided Political Heart: The Battle for the American Idea in an Age of Discontent. By E. J. Dionne, Jr. New York: Bloomsbury Publishing, 2012. 337p. \$27.00 cloth, \$18.00 paper.

The Spirit of Compromise: Why Government Demands It and Campaigning Undermines It. By Amy Gutmann and Dennis Thompson. Princeton: Princeton University Press, 2012. 256p. \$24.95.
\end{abstract}

It's Even Worse Than It Looks: How the American Constitutional System Collided with the New Politics of Extremism. By Thomas E. Mann and Norman J. Ornstein. New York: Basic Books, 2012. 242p. \$26.00.

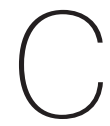
ommentary on contemporary American national politics is almost universally critical. Gridlock reigns: Politics is polarized, government is dysfunctional, and public policy is stalemated. Elected officials barely avoid one cliff only to find themselves on the brink of another. Credit downgrades, debt crises, national bankruptcy, climate catastrophe, and other forms of Armageddon loom. The system is broken.

The three books that are the subject of this review have a lot to say about the state of American politics today. All three accept the prevailing negative evaluation of the current scene, and none shares the contrarian views of those who argue that given the serious problems the country faces, the system actually is functioning reasonably wellindeed, as it was designed to function. ${ }^{1}$ But the current scene occupies a different status in the three books. For Thomas Mann and Norman Ornstein, Washington politics is front and center- the core of their book. For Amy Gutmann and Dennis Thompson, contemporary politics is in the background-the current manifestation of a generic problem faced by democratic polities. For E. J. Dionne, Jr., our current political scene reflects an imbalance in a centuries-long interplay between individualism and egalitarianism in American politics.

The styles of the books reflect the backgrounds and interests of the authors. Gutmann and Thompson are eminent political theorists. The Spirit of Compromise is the most abstract of these books, employing examples from current American politics throughout, but focused on issues

Morris P. Fiorina is the Wendt Family Professor of Political Science at Stanford University. He wishes to thank David Brady and John Ferejohn for their helpful comments. applicable to any democratic polity at any time. Like in many works of political theory, there is some hairsplitting, including a blizzard of conceptual innovations - "principled tenacity," "willful opposition," "principled prudence," and so on. Still, on the whole, the book is readable and insightful—even for nontheorists.

Mann and Ornstein wear two hats. They are political scientists but also respected observers and analysts of the Washington scene. Their book is the most concrete, focusing specifically on the conduct of politics in recent years. It's Even Worse Than It Looks presents a strong argument and will be of most interest to empirical political scientists and general readers.

Dionne is a nationally prominent journalist also with academic training (sociology). Our Divided Political Heart advances a broad philosophical argument embedded in a far-ranging historical survey in which the current scene is the latest episode. The longest of the three books, it is gracefully written as befits a professional journalist, and full of interesting historical material. Its argument will appeal to those who see ideas as major animators of political activity.

In works that discuss contemporary politics, it is not surprising that the authors' points of view enter their discussions. Gutmann and Thompson are relatively evenhanded. While noting that most observers believe the Republicans are more to blame for the present condition of American politics than the Democrats, they write that, "it would be a mistake to dwell on who is most to blame at the moment. . . . If it so happens that one party is more responsible for the polarization at a particular time, this should not distract us from the broader problem that needs to be addressed to make room for responsible governing" (p. 23).

Somewhat surprisingly, given the strong point of view expressed in many of his columns, Dionne's personal stance 
is less pronounced in his book. He argues that trends in contemporary conservatism have produced a Republican Party whose positions are outside the bounds of the historical balance between libertarianism and communitarianism in American politics: "What needs to be recognized is how far Republicanism and conservatism have strayed from their own history and their own past commitments" (p. 248).

As indicated by their title, Mann and Ornstein write in a tone of "J'accuse!" Despite Ornstein's long association with the American Enterprise Institute, a right-of-center think tank, he and Mann mince no words in laying our current political difficulties at the feet of a Republican Party they see as operating outside the boundaries of responsible behavior in politics and government.

Since I will quibble with some particulars of Dionne's and Mann and Ornstein's points of view, it is only fair to put my cards on the table. I have voted Libertarian in every election since 1980, having come to the conclusion in the late 1970s that Democratic economic policies and Republican social policies were similarly unacceptable, and that libertarian foreign policies were near my ideal point. I have no problem with bashing Republicans. But the Democrats should not get off unscathed.

Let us proceed.

\section{The Problem As Seen by the Authors}

Gutmann and Thompson postulate that "governing a democracy without compromise is impossible" (p. 1). But compromise has become increasingly difficult because an "uncompromising mindset" has replaced a "compromising mindset." The former emphasizes adhering to principle and mistrusting political opponents. The latter emphasizes adapting principles and respecting opponents.

Gutmann and Thompson deconstruct the concept of compromise. By compromise, they do not mean finding common ground - there may be none. Nor is compromise a logroll in which each side gives up something it values less in exchange for something it values more. Nor is compromise a matter of dividing up the spoils. If economic growth in the United States were to surge to 5\% per year and continue, then not too far down the road the federal government could lower tax rates and increase spending. This would not be a compromise in the Gutmann-Thompson sense. Rather, "classic compromise" hurts. It involves mutual sacrifice and "willful opposition": "The sacrifice involves not merely getting less than you want, but also thanks to your opponents, getting less than you think you deserve" (p. 10). Classic compromises "will include elements that are jointly incoherent and inconsistent with any single theory" (p. 37).

For Gutmann and Thomson, failure to compromise imposes two costs. The first falls on policy outcomes: Unwillingness to compromise increases the bias toward the status quo. The second falls on the democratic process: "Resistance to compromise undermines patterns of mutual respect that are essential for a robust democratic process" (p. 34).

Like Gutmann and Thompson, Dionne believes in the importance of ideas: "Underlying our political impasse is a lost sense of national balance that in turn reflects a loss of historical memory. ... The consensus that guided our politics through nearly all of the twentieth century is broken" (p. 4). The ideas that require balance are familiar to all readers-liberty and equality, and their political manifestations, libertarianism and communitarianism: "At the heart of this book is a view that American history is defined by an irrepressible and ongoing tension between two core values: our love of individualism and our reverence for community" (p. 4). For Dionne, it is not that one party embodies one value and the other party the other; rather, throughout history both parties have embodied both values, as have most citizens. The positions of the parties have been amalgams that balanced the two core values, but that balance has been upset (p. 68):

Our current polarization arises in part because liberals and Democrats - notably our last two Democratic presidents- have become more open to a communitarian view of our national story at the very moment when conservatives have been casting aside their own strong communitarian traditions and denying the robust role played by the federal government in the nation's growth and development from the earliest days of our republic.

Readers will hear echoes of earlier scholars in Dionne's account. One can read Samuel Huntington as addressing the cyclical tension between the individualistic "is" and a more communitarian ideal in the operation of American institutions. ${ }^{2}$ Even more closely, Robert Booth Fowler has argued that the individualism emphasized in the liberal tradition heightens the individual's need for something more, namely, religious community. But there is no cyclicity in Dionne as in Huntington, and contra Dionne, Fowler writes that, "it is a frequent error to place individualism and community at opposite and warring poles." ${ }^{3}$ For Dionne, the two are in a balance that may persist for an indeterminate period of time, as in the "long consensus" that he sees as prevailing throughout most of the twentieth century.

In Part II of the book, Dionne discusses the turn of conservative thought away from a traditional balanced conservative ideology to today's "post-Bush conservatism" that "has abandoned its communitarian sympathies for a defense of a pure and radical individualism" (pp. 122-23). Along the way he properly critiques the Glenn Beck school of history that is popular within the Tea Party (although Dionne's discussion of the Tea Party seems more measured in this work than in some of his earlier columns). ${ }^{4}$

In Part III, Dionne surveys the political-economic history of the United States, pointing out that the popular notion of the United States as a laissez-faire society that ended with the New Deal has little factual basis. The federal government has been intimately involved with social 
and economic development since the adoption of the Constitution-mariners' health care, the Postal Service, the Bank, canals, railroads, Civil War pensions, Mothers' pensions. At some length Dionne discusses Alexander Hamilton, Henry Clay, Abraham Lincoln, and Theodore Roosevelt-all forerunners of conservative thinking, concluding that the brand of conservatism embraced by today's Republican Party represents a sharp break with the past. Here, the reader will hear echoes of the manifesto of David Brooks and William Kristol for "national greatness conservatism," against which Tea Party conservatism is at least to some extent a reaction. ${ }^{5}$

By Dionne's reading, after a brief nineteenth-century interruption, the balance was restored and a long consensus characterized the twentieth century, only to fray late in the century. Today, "[w] ith nearly complete control of the Republican Party and hegemony within the conservative movement, radical individualism is as close to triumph as it has been at any point since the Gilded Age. Whether it will succeed or fail is now the central question in American politics" (p. 242).

Mann and Ornstein state their thesis clearly and strongly. It has two parts. First, although in an ideal-typical, responsible-parties system the parties are "ideologically polarized, internally unified, vehemently oppositional, and politically strategic" (p. 102), gridlock does not occur because the majority has full control of the government. But the development of political parties that operate like the responsible parties of mid-twentieth-century Britain guarantees gridlock in a democracy like ours that has separated institutions sharing powers, federalism, independent elections, and other features that provide minorities with numerous veto points. Second, while both parties have changed, let's not kid ourselves in the pursuit of fairness or "balance." There is "asymmetric polarization" (pp. 51-58): "[O]ne of the two major parties, the Republican Party, has become an insurgent outlier-ideologically extreme; contemptuous of the inherited social and economic policy regime; scornful of compromise; unpersuaded by conventional understanding of facts, evidence, and science; and dismissive of the legitimacy of its political opposition" (p. xiv).

\section{Roots of the Problem}

For Gutmann and Thompson, the ongoing demise of the compromising mind-set can largely be traced to the permanent campaign. Like Hugh Heclo, Guttman and Thompson argue that the permanent campaign has obliterated the traditional boundary between campaigning and governing. ${ }^{6}$ As zero-sum games, campaigns appropriately emphasize the uncompromising mind-set. "Principled tenacity" inoculates the candidate from the charge of flipflopping, and "mutual mistrust" is certainly advisable when the goal of the adversary is to do you in. But the uncompromising mind-set of the campaign "gets in the way of negotiating the deals required to pass laws in a pluralist society" (p. 204). For that, "principled adaptation" and "mutual respect" are necessary. The decline of compromise is a negative externality of the rise of the permanent campaign, or, as Gutmann and Thompson put it, "The uncompromising mindset is like an invasive species that spreads beyond its natural habitat as it roams from the campaign to the government" (p. 22).

Dionne attributes the current national stalemate to a change in the balance of ideas, but does not explain why contemporary conservatism upset the balance. There are hints in the historical survey, and political strategies are surely implicated. In one of his infrequent criticisms of the Left, for example, Dionne concedes that some elements such as the "counterculture" went too far in the later decades of the twentieth century, allowing the Right to claim populism, which he regards as a progressive movement (p. 209). All in all, though, the causal process by which ideas change remains largely unspecified.

Mann and Ornstein offer the most concrete explanations for the political situation they decry. While noting earlier abuses of congressional practice by the Democratic majority, they place a lot of blame on the nihilistic strategies followed during the House Speakership of Newt Gingrich (p. 43):

He crystallized the approach of crafting a cohesive, parliamentarystyle minority party and using it as a battering ram to stymie and damage a president of the other party. By moving to paint with a broad brush his own institution as elitist, corrupt, and arrogant, he undermined basic public trust in Congress and government, reducing the institution's credibility over a long period. His attacks on partisan adversaries in the White House and Congress created a norm in which colleagues with different views became mortal enemies. In nationalizing congressional elections, he helped invent the modern permanent campaign, allowing electoral goals to dominate policy ones; the use of overheatd rhetoric and ethics charges as political weapons; and the takeno-prisoner politics of confrontation and obstruction that have become the new normal.

As social scientists, Mann and Ornstein well know that the actions of no single individual fully explain major developments in American politics. Thus, they situate Gingrich in a context that includes other culprits that have been the subject of study by political scientists - demographic changes that have contributed to the process of party sorting, the rise of a partisan media and the development of new communications technologies that permit the spread of misinformation, the erosion of restraint and good taste in American popular culture, the sharp decline of trust in government officials and institutions, and the ever-expanding role of money in elections.

\section{What Is to Be Done?}

Readers will not be surprised that Gutmann and Thompson and especially Dionne are more convincing in describing the ideational correlates of gridlock than in identifying 
paths for improvement. Other than materialistic theories that view ideas as rationalizations of objective conditions, we do not have good theories of the ways in which ideas change, and Gutmann and Thompson, and Dionne do not seem to be materialists.

Gutmann and Thompson argue that improving the current state of the country requires a resurgence of the compromising mind-set. They offer a potpourri of suggestions: Move families to Washington in order to increase social contact among members of the political class. Restrict use of the filibuster to make obstruction more difficult. Increase term lengths to make the interelection period longer. Limit when and from whom officeholders can raise money in order to diminish electoral pressures and the time spent dealing with them. Institute open primaries in order to broaden the primary electorate and encourage greater political activity among people not part of the parties' bases. Strengthen civic engagement. And, notably, persuade the media to modify its framing of news about politics and government-less horse race coverage and fewer sports and battle analogies, more stories on substantive outcomes. While these generally seem like good ideas, I suspect that most readers will judge them as impractical and/or unlikely to make much difference.

Political communications research often concludes that the influence of the media is exaggerated, ${ }^{7}$ but Guttman and Thompson's assertion that "no institutions beyond government and elections have contributed more to making campaigns permanent than the media" (p. 189) will strike a chord with many readers. By framing legislative agreements in terms of wins and losses, the media increase base pressures on elected representatives and create perceptions of strength and weakness, competence and incompetence, and, importantly, winners and losers. Even if a compromise looks pretty good for your side, if it can be portrayed as even better for the other side, politicians can not be blamed for refusing to sign on. Shortly after the Obama administration and the Republican House narrowly avoided going over the fiscal cliff in January 2013, a CNN headline ran something like "New Washington Post Poll Finds That Majority Believes Obama Won Fiscal Cliff Showdown." "Headlines like that do not make it easier for Republicans to compromise on the next occasion.

Dionne intends his book as "a plea to restore and refresh the traditional American balance" (p. 16). How that might occur is Part III of the book-one short, final chapter. Dionne places his hope in the millennial generation, which he sees as resembling Robert Putnam's "long civic generation" (p. 254). ${ }^{9}$ According to Dionne, the millennials are both "more passionately individualistic and more passionately communitarian than any other age group in the country. ... Their sense of communal obligation is made manifest in their exceptional devotion to service. . . . They have more faith than their elders do in government's constructive capacities" (p. 253), and are "more likely than older cohorts to believe that government can be efficient" (p. 255). ${ }^{10}$ Whether the millennials will carry these orientations throughout their lives like the long civic generation remains to be seen.

Importantly, in advocating a return to balance, Dionne does not advocate a return to the particulars of the long consensus of the twentieth century. He envisions a new consensus that places less emphasis on big government: "For the new generation the model company is Apple, not General Motors" (p. 256). Civil society must be strengthened, and more talent must be drawn into public service, but Dionne is understandably vague on what the new consensus will look like.

Mann and Ornstein are by far the most explicit in discussing how to improve the current state of American politics. They begin by telling us "what is not to be done" in a list of "Bromides to Avoid" (pp. 107-30): Forget a centrist third party. Don't bother with a balanced budget amendment to the Constitution. Term limits are certainly not the answer. Public financing of elections is no magic bullet. (Most readers of this journal are familiar with the arguments.) The authors pin their hopes for improvement on "three avenues of electoral reform." First is "moderate politics by expanding the electorate" (p. 132). Right on! Unfortunately, while reforming registration and voting rules are good things to do, my reading of the literature on voting turnout does not suggest that such reforms will have a big impact. And while mandatory voting in federal elections is appealing in principle, it is just not going to happen.

A second avenue of reform involves lessening "the presumed bias against moderate voters and candidates by altering how votes in the election are converted into seats in government" (pp. 132-33). Again, many of us favor open primaries, but they are unlikely to have a major impactpartisans, ideologues, and cranks are still far more likely to vote. And the odds of adopting new electoral rules like instant runoff voting are probably in the same ballpark as those for mandatory voting.

Campaign finance is Mann and Ornstein's third avenue of reform. They recognize that this will be an uphill battle. Full disclosure will have many supporters, as will efforts to restrain super-PACs, leadership PACs, and lobbyist contributions (although I'm unclear how the proposed program of "matching grants" for small donors will lessen the influence of extremists). Unfortunately, the history of campaign finance reform illustrates the difficulty of carrying it out.

Not surprisingly, Mann and Ornstein also have institutional reforms in mind. They concede that establishing a parliamentary system is a reform too far, although they seem to look with some favor on abolishing midterm elections and giving members of the House four-year terms and senators four- or eight-year terms. More realistically, they propose restrictions on the use of the filibuster, and "to transfer more decision-making power from Congress 
to the executive branch" (p. 172). The latter proposal probably will be controversial among those old enough to remember the hand-wringing over the "imperial presidency" 40 years ago.

Mann and Ornstein conclude with an intriguing suggestion, that we need to "restore public shame" (p. 180). As Phillip K. Howard remarks, "Behavior that would seem grotesque to most Americans doesn't raise an eyebrow inside the Beltway." ${ }^{11}$ (Most recent case in point: newly confirmed Treasury Secretary Jack Lew. ${ }^{12}$ To those of us who came of age during a period of civil politics in the mid-twentieth century, this is an attractive suggestion (although skeptics regularly remind us that multiple injustices lay beneath that layer of civility). Mann and Ornstein call on the media, an informed public, and politicians themselves to elevate the level of political discourse and behavior.

\section{On Asymmetric Polarization}

In a Democratic-leaning discipline, Mann and Ornstein's broadside at the Republicans is relatively uncontroversial. But while most of us would agree with them on laying the preponderance of blame on the Republicans, I think that they let the Democrats off too easily. (I have known these authors for 40 years and in no way am I implying that there is any conscious bias in their view, just that there are considerations that should be added to the Democratic side of the blame scale).

William Galston, Mann's colleague at Brookings, writes that the thesis of asymmetric polarization is exaggerated. Democrats, as well as Republicans, have moved away from the center, though Republicans more so. ${ }^{13}$ I agree, particularly when one looks at Congress through a generational lens rather than one focused on the past six years. Contrast the divided Democratic Caucus of 1981-82 with the far more liberal caucus of 2010. And even more recently, we should not forget that the rise of the Tea Party is in some part a reaction against the "borrow and spend" Republican Congresses of the George W. Bush years.

Mann and Ornstein decry not only the extreme positions and legislative obstruction of Republicans but also tactics like attempting to delegitimate their opponents. Is there anything new or particularly exceptional here? I have to smile when old conservatives fulminate and call Obama a socialist. My sense is that as a serious scare term, "socialist" has been passé since the elections of Ronald Reagan and Margaret Thatcher a generation ago. For anyone under the age of 45 or so, "He's a socialist!" is just not a big deal. On the other hand, the fascist label still has some sting, given the association with racism and ethnocentrism. And labeling Republicans fascists is a smear long favored by Democrats. When Barry Goldwater won the Republican presidential nomination in 1964, California Democratic Governor Pat Brown commented that the "stench of fascism is in the air." ${ }^{14}$ And lest you think that this is ancient
history—Google "Mitt Romney fascist," let alone "George Bush fascist.”

I am too young to remember McCarthyism, but since that time I would say that the most common attempt to delegitimate opposition is the Democrats' playing of the race card. Beginning with the Moynihan Report in the 1960s, the first response of defenders of Democratic policies has frequently been an attack on the motives of critics. If you condemned urban riots in the late 1960s, you were probably a racist. Worried about crime? "Law and order" is a code term for racism. ${ }^{15}$ Concerned about family dissolution, drug abuse - even government spending? Such concerns probably were racially motivated, in the view of many Democrats. Certainly, racism exists, but to use it as the first response to policy criticism is unwarranted (not to mention politically counterproductive-it antagonizes people with legitimate concerns).

Mann and Ornstein also charge that Republicans are "unpersuaded by conventional understanding of facts, evidence, and science" (p. xiv). As a social scientist, I am similarly disheartened by this all-too-often displayed tendency among Republicans. But while Democrats seldom attain the colorful rhetorical lows that Republicans do ("All that stuff I was taught about evolution, embryology, the Big Bang theory —all of that is lies straight from the pit of hell"), ${ }^{16}$ when it comes to genetically modified food, energy production, or almost anything related to the environment, many Democrats are willing to accept the findings of "research scientists" working for interest groups over the less frightening findings of government and academic scientists. And, a bit farther out on the fringe, paranoia about vaccines seems mostly a Democratic thing. Republicans go farther than Democrats when science differs from religion and ideology, but Democrats are not model consumers of disinterested science either.

That Obama took office ready to put "an end to the petty grievances," "the recriminations and the worn-out dogmas" that "have strangled our politics" but was stymied by recalcitrant Republicans is a widely accepted characterization of recent politics. ${ }^{17}$ All readers will remember Mitch McConnell's (R-KY) comment that, "The single most important thing we want to achieve is for President Obama to be a one-term President." But contrary to claims (including the president's) that McConnell made the remark at the beginning of Obama's term, he made it on October 23, 2010, on the eve of the midterm elections about 21 months after Obama took office. ${ }^{18}$ Even Senator Jim DeMint's (D-SC) Waterloo comment ("If we're able to stop Obama on this, it will be his Waterloo, it will break him") came on July 17, 2009, six months after Obama took office. ${ }^{19}$

Were repeated Democratic attempts to compromise with Republicans rebuffed in those first six months? Consider the stimulus bill introduced on January 26, six days after President Obama was inaugurated. According to 
another respected observer of Washington politics, Bob Woodward, "The bill was drafted by the Democrats and whenever any Republican tried to make changes, [Rahm] Emanuel's response was, more often than not, 'We have the votes. Fuck'em.' "20

Some claim that even if not publicly expressed, the oppositional strategies of McConnell and DeMint had been adopted by congressional Republicans before Obama took office, and so compromise was impossible. ${ }^{21}$ How plausible is that argument? Obama had just won an impressive electoral victory and the Republicans had just suffered their second consecutive congressional "thumpin'." Talk of 2008 being a "transformative election" was rampant in pundit circles and some academic ones. Under these conditions, is it plausible that most Republicans would have decided that implacable opposition to the president's proposals was their optimal electoral strategy? By summer, however, Obama's approval rating among independents was falling, and the political world looked safe for the DeMints of the party to go into pure opposition mode.

I had very high hopes for Obama. In talking about gay friends in the red states and coaching Little League in the blue states, he was singing out of my hymnbook. But in delegating legislative operations to Chief of Staff Emanuel and Speaker Nancy Pelosi, he failed to take advantage of the opportunity - however slight - to move beyond those stale partisan conflicts of the past. Perhaps the Tea Party would have arisen just the same and short-circuited any move toward a less conflictual politics. But it seems to me that an alternative path was never seriously explored.

\section{On the End of the Long Consensus}

Why did Dionne's long consensus end? A materialist would naturally assume that the objective conditions underlying the consensus must have changed. Could it be that the resurgent appeal of radical individualism results from the balance shifting too far away from the individualist pole? This suggestion will strike many readers as preposterous. In the past several decades, public policies and societal norms have greatly increased the choices available for women, racial and ethnic minorities, and the lesbian, gay, bisexual, and transgender communities. And for everyone, individual self-expression now is championed to the point where even Dionne suggests that it may have gone too far at times.

All true. But at the same time, behavioral restrictions imposed at the behest of various governments have grown enormously. In 1979, James Q. Wilson wrote that, "[o]nce politics was about only a few things, now it is about nearly everything." 22 More recently, Bryon Jones shows empirically that since the 1950 s, the national agenda has broadened ("government moves into new areas previously reserved for civil society"), rather than thickened ("previously established government functions expand"). ${ }^{23}$ Nancy Burns documents this trend at the subnational level in her study of the proliferation of state and local governing bodies of all kinds. ${ }^{24}$

Today I cannot cut down a tree without an inspection and permit from a citizens' board in my town government. "Volunteer inspectors" from the community cruise neighborhoods on Christmas looking for smoking chimneys on a Spare the Air day. The "community" bans toys in Happy Meals at McDonald's restaurants, requires reusable grocery bags, and fines people for putting recyclables in the wrong colored bin. The community declares this park open to dog walkers and that park closed. Every day in myriad ways, laws and regulations adopted at the behest of various factions of the "community" restrict our behavior. Even if we recognize-and support-the publicpolicy aims of such restrictions, there is no denying that their cumulative impact on individual choice is significant. Ironically, one way to combat the appeal of radical individualism might be to lessen the interference of those purporting to speak for "the community" in our lives. ${ }^{25}$

Not only might it be the case that it is the communitarian side that has upset the balance, but I suggest that the behavior of their agents has further alienated a significant segment of the public. Dionne writes that "in a democracy, government is not the realm of 'them,' but of 'us, " decrying the tendency to view the two as separate adversarial spheres (p. 6; emphasis in original). What if many Americans outside the Beltway have decidedquite rationally-that the government is "them"? In the midst of an economic calamity, an income tax cheater and member of the Federal Reserve pressures AIG to pay off Goldman-Sachs 100 cents on the dollar, ${ }^{26}$ then as treasury secretary commits obstruction of justice in quashing criminal indictments in the HSBC case, ${ }^{27}$ and for his efforts receives not a jail term but probably a multimillion-dollar position on Wall Street (all of this in a Democratic administration). Can one blame citizens for believing their government is bought and paid for by "them"? (And while we're on the subject, why isn't John Corzine in jail? Evidently, "them" can get away with things "us" can't.)

When citizens read that the Washington area is an island of prosperity amid the misery of the Great Recession, can one blame them for thinking of the federal government as "them"? ${ }^{28}$ And as suggested previously, while Washington is the most visible example, at the state and local level programs for the poor, the sick, and the aged are slashed while the generous salaries and benefits of public employees are protected. Just before the proofs of this essay arrived, San Francisco Bay Area transit employees struck, throwing the daily commute into chaos. The union demanded a $23 \%$ pay increase over four years, no increase in their contribution to their pension plan (nothing), and no increase in their contribution to their health care plan (\$92/month, regardless of plan chosen and size of family, continuing in retirement). Even in what is arguably the most liberal city in the country, the strike was a public 
relations fiasco and the union returned to work without a contract. ${ }^{29}$ Former Democratic Mayor Willie Brown wrote, "There was a time when unions drew their strength from their image as the guy next door. These days, here's how the guy next door sees them: That's the early retiree who has a nicer car than me, a boat in the driveway and a pension and health care plan beyond my dreams." ${ }^{30}$ Perhaps Dionne and other elite journalists have consorted with "them" so long that they no longer understand why "us" might resent them.

So, while the concerns that motivate the authors of these three books are shared by most of us, I cannot find much ground for optimism in these books. The authors are serious thinkers who have laid out their diagnoses and proposed remedies. I applaud their efforts and hope that I am wrong about their books' capacities to produce progress on the problems that face us as a country. But historically, the sorts of problems our society faces today have produced chaotic politics. ${ }^{31}$ The problems of governance addressed by the authors are to some degree the consequences of the economic and social problems we face, as well as their cause. As in the past, I believe that the solutions to our governance problems are less likely to be philosophical than electoral. A new governing majority — when and if it arrives - will facilitate institutional change and eventually the emergence of a new governing philosophy.

\section{Notes}

1 Melnick 2013.

2 Huntington 1981.

3 Fowler 1989, 35.

4 E.g., Dionne, "The Tea Party: Populism of the Privileged," Washington Post, 19 April 2010, A15.

5 Brooks 1997.

6 Heclo 2000.

7 Mutz 2012.

8 I was at the gym and unable to write down the exact wording and the citation information.

9 Putnam, 2000, Chap. 14.

10 Not to sound too cynical, but have any studies attempted to separate out the degree to which volunteering reflects public spirit versus school communityservice requirements? Along the same lines, some scholars unkindly suggest that students use community service to enhance their college applications. See Wattenberg 2012, 153.

11 Howard 2012.

12 The Senate confirmed Lew by a vote of $71-26$. He left the Clinton administration to become a vice president of New York University at a salary of $\$ 800,000+$ and perks. In that capacity, he made Citigroup the "preferred lender" for student loans. He received a severance of $\$ 685,000$ when he left to work for, yes, Citigroup. When he left Citigroup to join the Obama administration in 2009, Lew received a bonus of $\$ 944,578$. Nearly three-fourths of the Senate thought this was all OK. I would bet my house that $71 \%$ of voters outside the Beltway would not have voted to confirm him. See MacGillis 2013.

13 Galston 2012.

14 Perlstein 2008. Goldwater has since been rehabilitated as a "reasonable conservative."

15 Scammon and Wattenberg 1970, 168.

16 The remarks are by Representative and (medical) doctor Paul Broun (R-GA), as quoted in Viebeck 2012.

17 First Inaugural Address. Obama 2009.

18 Kessler 2012.

19 Smith 2009.

20 Woodward 2012.

21 Grunwald 2012.

22 Wilson 1979.

23 Jones 2012.

24 Burns 1994.

25 In the formal theory literature, there is a widely accepted model called the setter model (Romer and Rosenthal 1978). One implication of the model is that the farther public policy is from the median voter, the more extreme the policy on the other side of the spectrum that can defeat it (so long as it is marginally closer to the median). So, when seemingly radical positions gain considerable support, that may be an indication that the status quo is radical.

26 Corkery 2010.

27 Black 2012.

28 Ferguson 2012.

29 Matier and Ross 2013; Garafoli 2013.

30 Brown, "Public Workers Union Should Work on Their PR," San Francisco Chronicle, July 7, C9.

31 Fiorina 2013.

\section{References}

Black, William K. 2012. “The Second Great Betrayal: Obama and Cameron Decide that Banks Are Above the Law." http://neweconomicperspectives.org/2012 /12/the-second-great-betrayal-obama-and-cameron -decide-that-banks-are-above-the-law.html (accessed January 28, 2013).

Brooks, David. 1997. "A Return to National Greatness." http://www.weeklystandard.com/Content/Protected /Articles/000/000/008/333pjkmj.asp?page $=3$ (accessed March 6, 2013).

Burns, Nancy. 1994. The Formation of American Local Governments. New York: Oxford University Press.

Corkery, Michael. 2010. "AIG Bailout Keeps Dogging Tim Geithner." http://blogs.wsj.com/deals/2010/01 /07/aig-bailout-keeps-dogging-tim-geithner/ (accessed January 28, 2013). 
Ferguson, Andrew. 2012. "Bubble on the Potomac." http://www.time.com/time/magazine/article /0,9171,2115062,00.html (accessed January 30, 2013).

Fiorina, Morris P. 2013. "The Missing Moderates." The American Interest 9: 58-67.

Fowler, Robert Booth. 1989. Unconventional Partners: Religion and Liberal Culture in the United States. Grand Rapids, MI: Eerdmans.

Galston, Bill. 2012. "Why Republicans Aren't the Only Ones to Blame for Polarization." http://www .newrepublic.com/article/the-vital-center/103394 /polarization-norm-ornstein-republicans-democrats\# (accessed January 10, 2013).

Garafoli, Joe. 2013. "No Politician Likely to Try to Stop BART Strike." San Francisco Chronicle (August 9). http://www.sfchronicle.com/politics/joegarofoli /article/No-politican-likely-to-try-to-stop-BART -strike-4719505.php (accessed August 15, 2013).

Grunwald, Michael. 2012. "The Party of No: New Details on the GOP Plot to Obstruct Obama." http://swampland.time.com/2012/08/23/the-party -of-no-new-details-on-the-gop-plot-to-obstruct -obama/ (accessed February 14, 2013).

Heclo, Hugh. 2000. "The Permanent Campaign: A Conspectus." In Campaigning to Govern or Governing to Campaign, ed. Thomas Mann and Norman Ornstein. Washington, DC: The Brookings Institution.

Howard, Philip K. 2012. "Reform Is Not Enough: The Federal Government Needs a Complete Makeover." http://www.theatlantic.com/politics/archive/2012/08 /reform-is-not-enough-the-federal-government-needs -a-complete-makeover/260669/ (accessed February 1, 2013).

Huntington, Samuel P. 1981. American Politics: The Promise of Disharmony. Cambridge, MA: Harvard University Press.

Jones, Bryan D. 2012. "The Dynamics of Agenda Expansion and Contraction in the U.S." Paper presented at Stanford University American Politics Workshop.

Kessler, Glenn. 2012. "When Did McConnell Say He Wanted to Make Obama a 'One-Term President'?" http://www.washingtonpost.com/blogs/fact-checker /post/when-did-mcconnell-say-he-wanted-to-make -obama-a-one-term-president/2012/09/24/79fd5cd8 -0696-11e2-afff-d6c7f20a83bf_blog.html (accessed January 28, 2013).

MacGillis, Alex. 2013. "Why Did Democrats Give Jack Lew a Pass?" http://www.newrepublic.com/article /112548/jack-lew-confirmed-treasury-secretary -democrats-gave-him-pass (accessed March 5, 2013).

Matier, Phillip and Andrew Ross. 2013. "Major Politicians Steer Clear of BART Strike." San Francisco Chronicle (July 3). http://www.sfchronicle.com/ bayarea/matier-ross/article/Major-politicians-steerclear-of-BART-strike-4643970.php (accessed August 15, 2013).

Melnick, R. Shep. 2013. "The Gridlock Illusion.” The Wilson Quarterly. http://www.scribd.com/doc /140661201/The-Gridlock-Illusion-WQ-Magazine (accessed January 18, 2013).

Mutz, Diana. 2012. "The Great Divide: Campaign Media in the American Mind.” Daedalus 141(4): 83-97.

Obama, Barack. 2009. Inaugural Address. http:// www.whitehouse.gov/blog/inaugural-address/ (accessed February 15, 2013).

Perlstein, Rick. 2008. "1964 Republican Convention: Revolution from the Right." http://www .smithsonianmag.com/history-archaeology/1964 -republican-convention.html (accessed February 1, 2013).

Putnam, Robert D. 2000. Bowling Alone. New York: Simon \& Schuster.

Romer, Thomas, and Howard Rosenthal. 1978. "Political Resource Allocation, Controlled Agendas, and the Status Quo." Public Choice 33: 27-43.

Scammon, Richard M., and Ben J. Wattenberg. 1970. The Real Majority. New York: Coward, McCann \& Geoghegan.

Smith, Ben. 2009. "Health Reform Foes Plan Obama’s 'Waterloo.' " http://www.politico.com/blogs/bensmith /0709/Health_reform_foes_plan_Obamas _Waterloo.html (accessed January 30, 2013).

Viebeck, Elise. 2012. "Republican Says Evolution, Big Bang Theory 'Lies Straight from the Pit of Hell'." http://thehill.com/blogs/blog-briefing-room/news /260641-house-republican-says-evolution-big-bang -theory-lies-straight-from-the-pit-of-hell- (accessed January 28, 2013).

Wattenberg, Martin P. 2012. Is Voting for Young People? $3 \mathrm{~d}$ ed. New York: Pearson.

Wilson, James Q. 1979. "American Politics, Then and Now." Commentary (February): 39-46.

Woodward, Bob. 2012. The Price of Politics. New York: Simon \& Schuster. 